\title{
Pengelupasan Grafit untuk Mengkomersilkan Teknologi Grafin
}

(Graphite Exfoliation to Commercialize Graphene Technology)

\author{
KIM S SIOW*
}

\section{ABSTRAK}

Kertas ini mengkaji teknologi pengelupasan untuk menghasilkan grafin, grafin oksida (GO) dan grafin oksida terturun (rGo). Empat teknologi pengelupasan yang utama dikenal pasti dalam tinjauan ini iaitu pengelupasan mekanik, pengelupasan cecair, interkalasi-pengelupasan dan pengoksidaan-pengelupasan-penurunan. Setiap teknologi ini dibincangkan daripada segi kualiti grafin, grafit nanoplat, GO dan rGO yang dihasilkan dan langkah utama proses termasuk bahan kimia yang digunakan. Kami juga membuat satu kajian kemudah-capaian dan analisis sensitiviti untuk menubuhkan satu kilang penghasilan grafin yang berasaskan teknologi pengelupasan, saiz pasaran grafin dan bahan mentahnya iaitu grafit. Berdasarkan kitar gemburan Gartner, teknologi dan produk yang berasaskan grafin terletak di tiga lokasi iaitu lembah kekecewaan, cerun pencerahan dan dataran tinggi produktiviti.

Kata kunci: Grafin; grafin oksida terturun; grafit; pengelupasan; interkalasi

\section{ABSTRACT}

This paper surveys the main exfoliation technologies to produce graphene, graphene oxide or reduced graphene oxide $(r G O)$. The four main exfoliation technologies are known as mechanical exfoliation, liquid exfoliation, intercalationexfoliation and oxidation-exfoliation-reduction. The qualities of graphene, graphite nanoplate, GO and rGO and the different process steps as well as the chemicals used in these four techniques are discussed in this paper. The review also includes the feasibility and sensitivity analysis of setting up exfoliation-based graphene factory, the market size of graphene and its feedstock i.e. graphite. Depending on the application of the graphene-enabled product, the respective technologies are located either in the trough of disillusionment, slope of enlightenment and plateau of productivity in the Gartner hype cycle.

Keywords: Exfoliation; graphene; graphite; intercalation; reduced graphene oxide

\section{PENGENALAN}

Grafin merupakan satu lapisan karbon atom yang dwidimensi dan berbentuk heksagon yang disambungi oleh ikatan $\mathrm{sp}_{2}$. Teknologi grafin ini menarik perhatian ramai selepas hadiah Nobel dianugerahkan kepada Andre Geim dan Konstantin Novoselov untuk kajian grafin mereka pada tahun 2010. Dalam kalangan penyelidik, populariti grafin jelas kelihatan berdasarkan jumlah paten dan terbitan akademik dengan kata-kunci 'grafin' yang dilaporkan dari tahun 2005 sehingga tahun 2014 atau 2015 (Rajah 1).

Berdasarkan Jadual 1, grafin memiliki sifat mekanik, elektrik dan terma yang sesuai untuk dieksploitasikan untuk kegunaan elektronik, komposit dan bateri. Walaupun karbon nanotiub (CNT) juga mempunyai ciri yang hampir mirip dengan grafin tetapi harga grafin adalah berlipat ganda lebih murah daripada harga CNT. Harga grafin untuk $1 \mathrm{~kg}$ cuma antara AS\$40 dan AS\$100 (Sciences 2016) manakala harga CNT melebihi AS $\$ 7000$ untuk berat yang sama (SigmaAldrich). Oleh itu, grafin yang menjadi tumpuan pengkomersilan dalam kalangan penyelidik, pelabur-pelabur swasta dan kerajaan.

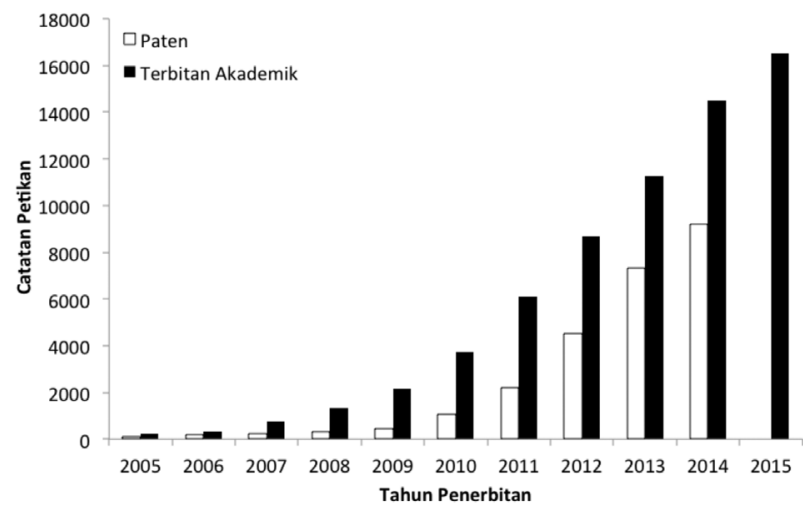

RAJAH 1. Catatan berkaitan teknologi grafin dari tahun 2005 ke 2014 (paten(UK-IP-Office 2015)) dan 2015 (catatan akademik yang dipetik dari Scopus pada $30 \mathrm{hb}$ November 2016)

Walaupun banyak kertas kerja tentang grafin diterbitkan (Rajah 1), kertas kajian ini akan menilai kemudah-capaian sebuah kilang grafin yang berteraskan teknologi pengelupasan, struktur kos dan kajian sensitivitinya. Dalam kajian ini, kami juga mengulas tentang jenis grafin dan kegunaannya, teknologi 
JADUAL 1. Pembandingan antara grafin dan karbon nanotiub (CNT) daripada segi mekanik, kimia dan fizikal (Edwards \& Coleman 2013; Novoselov et al. 2012; Pei \& Cheng 2012; Pop et al. 2006; Spitalsky et al. 2010; Thostenson et al. 2001)

\begin{tabular}{clcc}
\hline No & Parameter & Grafin & CNT \\
\hline 1 & Modulus elastik $(\mathrm{TPa})$ & 1 & $>1$ \\
2 & Kekuatan muktamad $(\mathrm{GPa})$ & 130 & $11-63$ \\
3 & Konduktiviti electrik $(\mathrm{S} / \mathrm{m})$ & 10000000 & 200 \\
4 & Konduktiviti terma $(\mathrm{W} / \mathrm{mK})$ & $>3000$ & 3500 \\
\hline
\end{tabular}

*Ciri-ciri ini bergantung kepada jenis CNT sama ada jenis satu dinding (SWCNT) atau pelbagai dinding (MWCNT), arah lateral atau paksi membujur

pengelupasan sedia ada di pasaran serta saiz pasaran grafin dan grafit. Kertas ini diakhiri dengan pembentangan cabaran yang dihadapi oleh industri grafin dan cadangan untuk menanganinya.

\section{JENIS, KEGUNAAN DAN TEKNOLOGI PENGHASILAN GRAFIN}

Sejajar dengan perkembangan grafin yang pesat, pelbagai definisi yang mengelirukan wujud di pasaran komersial mahupun kertas akademik untuk menerangkan struktur dan morfologi grafin. Sebagai contohnya, nama 'grafin nanoplatlet' atau 'grafin platelet' digunakan secara meluas untuk menerangkan grafin pelbagai lapisan yang mempunyai ketebalan atau saiz lateral yang kurang daripada $100 \mathrm{~nm}$ dan dikelupaskan daripada grafit, sedangkan definisi yang lebih sesuai untuk morfologi dan proses ini ialah 'grafit nanoplat' atau 'grafit nanohelaian' atau 'grafit nano-serpihan' (Bianco et al. 2013). Kertas kajian ini menggunakan 'grafit nanoplat' untuk menerangkan grafin yang mempunyai ketebalan kurang daripada 100 nm. Grafin 'dwi-lapisan', 'tri-lapisan', 'pelbagai lapisan' dan 'multi-lapisan' digunakan untuk mendefinisikan grafin yang mempunyai dua sehingga sepuluh lapisan grafin yang melekat pada substrat atau merupakan satu arca bebas daripada sebarang lekatan pada substrat (Bianco et al. 2013). Jadi, terma 'grafin multi-lapisan' digunakan di dalam kertas kajian ini untuk merujuk kepada grafin yang mempunyai lebih daripada satu lapisan grafin tetapi kurang daripada ketebalan 100 nm. Terma 'multi-lapisan' digunakan secara am untuk memudahkan perbincangan di dalam kertas ini. Di sini, harus ditegaskan bahawa ciri yang tertulis dalam Jadual
1 mungkin berlainan antara grafin mono-lapisan dan dwi-lapisan daripada grafin pelbagai-lapisan atau multilapisan (Choi et al. 2010).

Berdasarkan definisi ini, jenis grafin yang berada di pasaran boleh dikategorikan secara am kepada grafit nanoplat dan grafin multi-lapisan. Grafit nanoplat digunakan di dalam produk seperti dakwat konduktif, elektrod bateri, komposit berfungsi dan superkapasitor. Aplikasi yang melibatkan grafin multi-lapisan pula dibahagikan kepada aplikasi elektronik yang memerlukan mobiliti elektron yang tinggi seperti transistor dan aplikasi elektronik yang kurang kritikal seperti elektronik tercetak, elektrod lutsinar dan optoelektronik (Novoselov et al. 2012). Ketiga-tiga jenis aplikasi ini mempunyai tarikannya yang tersendiri walaupun bidang simpanan tenaga dijangka menyumbang $25 \%$ dan komposit pula menyumbang $40 \%$ daripada pasaran grafin menjelang tahun 2026 (Ghaffarzadeh 2016). Ramalan ini sejajar dengan Rajah 2 yang menunjukkan jumlah paten terkumpul yang difailkan dalam bidang komposit dan penyimpanan tenaga (elektrod) untuk teknologi grafin adalah terbanyak selepas 'teknologi pengeluaran grafin' pada tahun 2015 (Peplow 2015). Aktiviti paten ini juga selari dengan terbitan akademik untuk grafin, komposit dan penyimpanan tenaga/bateri (elektrod) yang dikumpul daripada laman web Scopus.com (Rajah 3). Grafin digunakan sebagai elektrod untuk meningkatkan keupayaan dan kapasiti pengecasan semula bateri ionlitium. Pasaran bateri ion litium ini dijangka mencapai AS\$46 bilion menjelang tahun 2022 dengan kadar pertumbuhan tahunan kompaun sebanyak 10.8\% (Szostak 2016).

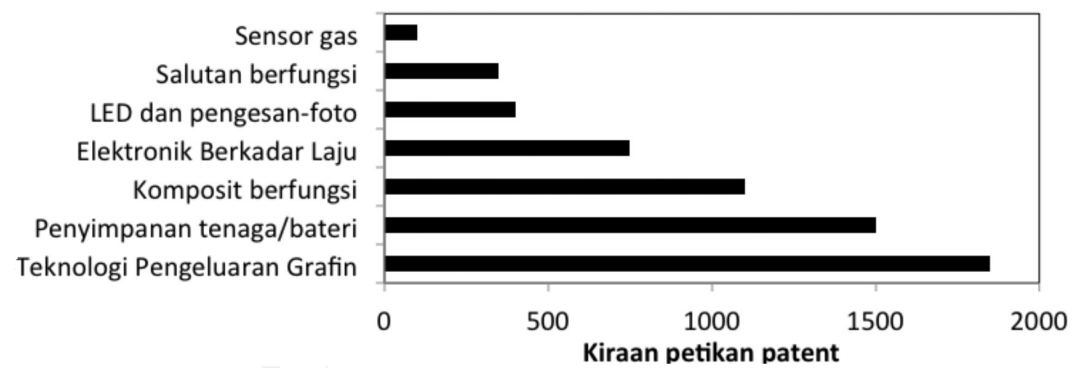

RAJAH 2. Bidang paten yang terlibat dalam teknologi grafin pada tahun 2015 (Peplow 2015) 


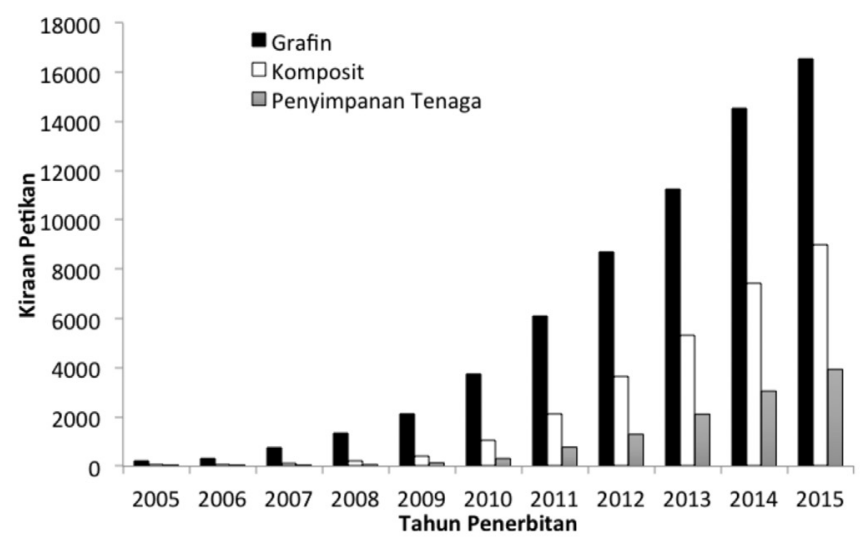

RAJAH 3. Kiraan petikan untuk kata kunci 'grafin', 'komposit' dan 'penyimpanan tenaga' seperti direkod dalam Scopus pada 30hb November 2015

Seterusnya, kami mengkaji teknologi yang sesuai untuk menghasilkan grafit nanoplat dan grafin multilapisan untuk kegunaan sektor komposit dan penyimpanan tenaga/bateri. Rajah 4 menunjukkan enam cara utama untuk menghasilkan grafin walaupun teknologi ini boleh dibahagikan kepada dua teknik utama iaitu pertumbuhanpemendapan grafin yang melibatkan teknologi vakum dan pengelupasan grafin. Teknologi vakum juga dikenali sebagai teknik 'bawah-ke-atas' kerana ia melibatkan penyusunan atom karbon untuk membentuk lapisan grafin tersebut. Teknologi pengelupasan pula dikenali sebagai teknik 'atas ke bawah' kerana ia mericihkan lapisan grafit untuk menjadi grafit nanoplat atau grafin multi-lapisan. Secara amnya, Rajah 4 menunjukkan teknologi yang biasanya digunakan untuk menghasilkan grafin berkualiti tinggi tetapi teknik ini pula jarang diguna pakai pada penghasilan berskala komersial.

Skop kertas ini memberi tumpuan kepada proses penghasilan grafit nanoplat dan grafin multi-lapisan berdasarkan teknik pengelupasan kerana teknik ini menghasilkan grafin yang memenuhi keperluan dan aplikasi utama dalam bidang komposit dan penghasilan bateri.

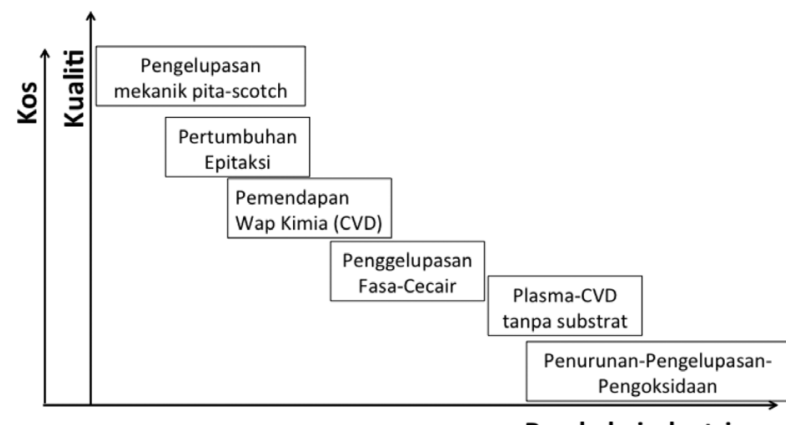

Berskala industri

RAJAH 4. Teknik pengeluaran industri berdasarkan kos, kualiti dan kebolehan untuk diskalakan ke tahap industri (Ghaffarzadeh 2016)

\section{PENGHASIlAn GRAFIn SECARA PENGELUPASAN}

Proses pengelupasan grafit memerlukan satu sumber tenaga untuk mengatasi daya van der Waals yang mengikat lapisan-lapisan grafin di dalam struktur grafit untuk menjadi grafin multi-lapisan atau grafit nanoplat. Rajah 5 menunjukkan peningkatan terbitan akademik yang menggunakan kata-kunci 'pengelupasan grafin' dan dua teknik utama iaitu 'mekanik' dan 'cecair' dari tahun 2005 ke tahun 2015. Oleh kerana jumlah penerbitan yang begitu banyak, kami cuma boleh mengulas sebahagian kecil daripada penerbitan tersebut secara selektif dan meminta maaf kepada penyelidik yang kami tidak sempat senaraikan dalam kertas kerja ini. Para pembaca yang berminat boleh merujuk kepada kertas kajian tentang penghasilan grafin di rujukan berikut (Bonaccorso et al. 2012; Choi et al. 2010; Ciesielski \& Samorì 2014; Edwards \& Coleman 2013; Parviz et al. 2016; Zhu et al. 2010).

Sebenarnya, teknik pengelupasan grafit boleh dibahagikan kepada empat teknik yang utama seperti yang ditunjukkan dalam Jadual 2, walaupun terdapat pertindihan dalam teknik tersebut. Teknik 1 hingga 3 (Jadual 2) biasanya menghasilkan grafit nanoplat dan grafin multi-

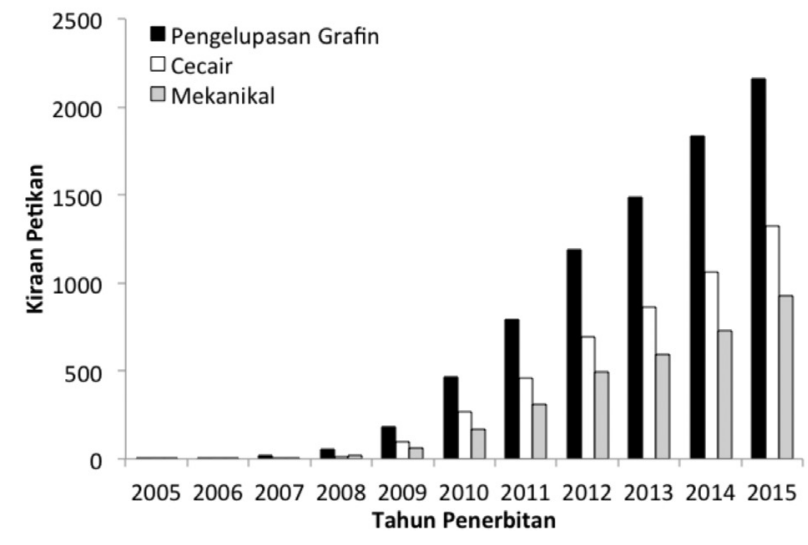

RAJAH 5. Kiraan petikan untuk kata kunci 'pengelupasan grafin' dan sub-setnya daripada segi 'mekanik' atau 'cecair' seperti yang direkod dalam Scopus pada 30hb November 2015 
JADUAL 2. Teknik dan langkah utama untuk mengelupaskan grafit kepada grafin, grafin oksida (GO) atau grafin oksida yang terturun (rGO) (Ren \& Cheng 2014)

\begin{tabular}{cll}
\hline No & \multicolumn{1}{c}{ Teknik } & \\
\hline 1 & Pengelupasan mekanik & 1) Penggilingan bebola \\
& & 2) Penyepuhlindapan terma \\
2 & Pengelupasan cecair & Penggilingan bebola/sonikasi/pericihan dalam cecair akues or organik atau polimer \\
3 & Interkalasi-pengelupasan & 1) Pemanasan, pengacauan dan tindakan elektrokimia \\
& & 2) Pemanasan gelomobang mikro dan tindakan kimia \\
4 & 3) Sonikasi untuk pengelupasan \\
& Pengoksidaan-pengelupasan - & 1) Pengoksidaan \\
& 2) Sonikasi/pengacauan dengan pemanasan atau gelombang mikro \\
\end{tabular}

lapisan (bergantung kepada keadaan proses) manakala teknik 4 pula menghasilkan grafin oksida terturun (rGO) atau grafin berfungsi. Setiap teknik pengelupasan ini akan dibincangkan seterusnya.

\section{PENGELUPASAN MEKANIK}

Walaupun pengelupasan grafit secara mekanik ala pita-scotch hanya dilaporkan pada tahun 2004, sejarah pengelupasan mekanik adalah panjang sebab teknologi ini juga digunakan oleh industri mineral seperti silika, garnet, alumina dan magnetit. Pengelupasan grafit secara mekanik ala pita scotch boleh menghasilkan grafin monolapisan yang mencapai keluasan $10 \mu \mathrm{m}^{2}$ tetapi teknik ini mempunyai hasil yang rendah dan hanya sesuai untuk penyelidikan dalam makmal (Novoselov et al. 2004).

Dalam pada itu, teknologi pengelupasan mekanik berskala industri yang paling awal ialah teknologi kepunyaan Cornerstone Tech yang merupakan satu pengisar berperingkat yang menggunakan jet air bertekanan tinggi untuk memecahkan grafit kepada serpihan kecil sebelum dironggakan di kebuk seterusnya dan dikisar oleh satu 'kolider' di peringkat ketiga (Mazurkiewicz \& Conrad 1999). Semasa pengisaran, kadar ricih yang melebihi $1000 \mathrm{~s}^{-1}$ digunakan untuk menghasilkan grafit nanoplat (Coleman \& Paton 2013). Cecair yang digunakan dalam pengisaran ini mempunyai kelikatan yang rendah, ketumpatan yang tinggi serta takat didih yang rendah (dalam lingkungan $50^{\circ} \mathrm{C}$ ) untuk memudahkan resapan dan penggelupasan grafit (Mazurkiewicz \& Conrad 1999). Contoh cecair yang sesuai untuk tujuan ini ialah cecair karbon dioksida, cecair nitrogen, cecair perflurokarbon dan cecair super-genting yang lain (Mazurkiewicz \& Conrad 1999). Campuran cecair lain yang juga menghasilkan pulangan yang baik ialah polimer polivinil alkohol dengan natrium kolate (Paton et al. 2014).

Satu lagi pengelupasan mekanik ialah menggunakan aliran jet untuk menghempaskan grafit ke dalam satu kebuk dengan kelajuan antara 100 hingga $1000 \mathrm{~ms}^{-1}$ (Hasegawa \& Kamiya 2016). Grafit ini juga boleh dirawat dengan penyepuhlindapan terma, sonikasi atau perubahan tekanan untuk meningkatkan produktiviti sebelum grafit dihempas dengan aliran jet (Hasegawa \& Kamiya 2016). Selepas pengelupasan mekanik dengan aliran jet, grafit nanoplat yang terhasil dibersihkan dengan rawatan ozon ultra-ungu atau plasma atmosfera atau plasma vakum (Hasegawa \& Kamiya 2016).

Selain aliran jet dan kisaran mekanik, pericihan grafit juga dikaji oleh ahli-ahli sains dari Pusat Kebangsaan bagi Penyelidikan Sains Perancis (CNRS) dan University Strasbourg (Janowska et al. 2009). Mereka mericihkan grafit dengan substrat seperti kaca atau silikon secara berterusan dalam satu lingkaran (Janowska et al. 2009). Kemudian, substrat tersebut direndam dan disonikasikan dalam larutan yang mengandungi agen penurun seperti hidrazina, ammonia dan natrium borohirida $\left(\mathrm{NaBH}_{4}\right)$ untuk menurunkan sebarang grafit oksida yang mungkin terhasil dalam proses pericihan (Janowska et al. 2009). Larutan ini dimendap dan diemparkan untuk mengumpul grafit nanoplat yang terhasil (Janowska et al. 2009).

Selain itu, teknik pengilingan-bebola melamina dengan grafit di dalam atmosfera nitrogen juga boleh menghasilkan grafit nanoplat yang berkualiti tinggi dengan nisbah keamatan spektra Raman $\mathrm{I}_{\mathrm{D}} / \mathrm{I}_{\mathrm{G}}$ serendah 0.6 (León et al. 2011). Kemudian, grafit nanoplat ini boleh ditapiskan daripada melamina dan diserakkan dalam dimetilformamida (DMF) (León et al. 2011). Selain melamina, teknik ini juga boleh digunakan bersama ammonia borana $\left(\mathrm{NH}_{3} \mathrm{BH}_{3}\right)$ untuk meresapi grafit dan melemahkan daya van der Waals di dalam grafit tersebut sebelum langkah pengilingan bebola dijalankan (Liu et al. 2013). Dua puluh lima peratus daripada grafin yang terhasil daripada teknik ini adalah grafin mono-lapisan walaupun kecacatan muncul pada satah basal grafin tersebut (Liu et al. 2013).

Dalam pada itu, sulfur juga pernah digunakan untuk menggantikan fungsi pita scotch untuk mengelupaskan grafit semasa penggilingan campuran grafit dengan bebola besi selama 3 hingga 6 jam (Lin et al. 2013). Interaksi kimia antara atom sulfur dan lapisan grafit adalah lebih kuat daripada ikatan van der Waals di antara lapisan grafin di dalam grafit tersebut (Lin et al. 2013). Walaupun penggunaan $\mathrm{NH}_{3} \mathrm{BH}_{3}$ dan sulfur dalam pengelupasan mekanik menyerupai teknik 'interkalasi - pengelupasan' (dibincangkan seterusnya), kami senaraikan kedua-dua penyelidikan tersebut di sini kerana langkah pengilingan 
bebolalah yang memberi daya ricihan untuk menghasilkan grafit nanoplat.

\section{PENGELUPASAN CECAIR}

Secara amnya, teknik pengelupasan cecair mengandungi tiga langkah iaitu penyerakan, pengelupasan dan penulenan walaupun langkah penyerakan dan pengelupasan boleh berlaku pada masa yang sama di dalam fasa cecair. Pembentukan dan pengempisan gelembung udara yang dihasilkan oleh ultrasonik akan mericih dan melonggarkan lapisan-lapisan grafin di dalam grafit tersebut.

Dalam pada itu, pelarut dalam fasa cecair perlu menyeimbangkan daya tarikan antara lapisan-lapisan grafin dengan mengurangkan tegangan-antara-muka antara grafit dengan pelarut. Pelarut yang sesuai untuk tujuan ini mempunyai tenaga permukaan dalam lingkungan $40 \mathrm{~mJ} / \mathrm{m}^{2}$ (Hernandez et al.2008). Contoh pelarut yang sesuai ialah $\mathrm{N}$-metilpirolidon (NMP), di-metilformamida (DMF) dan diklorobenzena (DCB) tetapi malangnya, semua pelarutpelarut ini adalah toksik dan takat didihnya juga agak tinggi (Hernandez et al. 2008). Oleh sebab itu, pelarut lain yang pernah dikaji untuk tujuan yang sama ialah asetonitril (Qian et al. 2009), 1-heksil-3-metil-imidazolium heksaflurfosfat (Nuvoli et al. 2011), aseton, kloroform dan isopropanol (O’Neill et al. 2011) serta pelarut aromatik perflurinated seperti pentaflurobenzonitril dan pyridina (Bourlinos et al. 2009). Walaupun pelarut ini adalah lebih mesra-alam dan takat didihnya adalah lebih rendah daripada yang lain, setiap pelarut ini masih mempunyai kelemahannya yang tersendiri seperti grafit nanoplat yang terhasil adalah agak tebal, pelbagai saiz dan kurang stabil semasa penyimpanan. Salah satu strategi untuk menangani masalah ini ialah mencampurkan dua pelarut mesra-alam seperti etanol dan air untuk menghasilkan jarak parameter kelarutan Hansen (HSP) yang minimum untuk memastikan kelarutan yang paling tinggi dengan grafit (Zhou et al. 2011). Nisbah pelarut etanol dengan air yang sesuai untuk mencapai kelarutan maksimum ini ialah 40\% (Chia et al. 2014) dan strategi ini juga boleh digunakan untuk pelarut asid yang lain seperti asid laktik dan asid sitrik (Chia et al. 2016). Walaupun begitu, langkah penulenan secara penapisan atau emparan biasa dijalankan untuk mengasingkan grafit nanoplat tersebut.

Selain pelarut, surfaktan juga digunakan untuk membantu proses pengelupasan dan menstabilkan lapisan atau grafit nanoplat yang terhasil di dalam larutan tersebut. Salah satu surfaktan tersebut ialah kompaun pirena dan kajian tersebut mendapati asid natrium1-pirena-sulfonik (Py-SO $\mathrm{SO}_{3}$ adalah yang paling berkesan untuk menghasilkan grafin mono-lapisan yang berkepekatan setinggi 0.8$1.0 \mathrm{mg} / \mathrm{mL}$ (Parviz et al. 2012). Kajian seterusnya menunjukkan kehadiran dwikutub pada molekul surfaktan seperti pirena adalah tidak sepenting fungsinya untuk menjerap dan menggalakkan anjakan sisi molekul air antara surfaktan dan grafin (Schlierf et al.2013). Kestabilan grafit nanoplat yang terhasil bergantung kepada $\mathrm{pH}$ dalam larutan koloid bukan caj dwikutub pada molekul tersebut
(Schlierf et al. 2013). Selain daripada pirena, natrium dodesilbenzena sulfonat (SDBS) juga pernah digunakan sebagai surfaktan untuk menghasilkan grafin multi-lapisan yang berkualiti tinggi; $43 \%$ daripada hasil ini mempunyai kurang daripada 5 lapisan dan apabila mendapan ini dikitarsemula, peratusan tersebut meningkat ke 67\% (Lotya et al. 2009). Kitaran semula adalah satu cara yang paling kos efektif untuk meningkatkan peratusan hasil, walaupun harga grafit adalah agak rendah (AS\$1-2/kg), sebab kitaran semula adalah mesra-alam dan kos overhednya adalah lebih rendah daripada penggunaan grafit asli (Parviz et al. 2016).

Selain daripada itu, pelarut organik yang digunakan dalam pengelupasan grafit dalam fasa cecair ialah pofirin yang dilarutkan di dalam NMP yang bercampuran dengan ion ammonium organik yang berlebihan (Geng et al. 2010). Interkalasi ion ammonium dan interaksi daya antara pofirin dengan lapisan grafin secara ikatan $\pi-\pi$ akan mengelupaskan grafit tersebut. Cara ini boleh menghasilkan lapisan grafin monolapisan yang berkualiti tinggi tanpa kecacatan walaupun produktivitinya tidak dibincangkan dalam penyelidikan tersebut. Polimer seperti polietilena bercabang hiper (HBPE) juga boleh digunakan untuk membantu pengelupasan grafit (Xu et al. 2013). HBPE yang terlekat dengan lapisan grafin akan memberi kestabilan sterik kepadanya dan teknik ini memberi kepekatan setinggi $3.4 \mathrm{mg} / \mathrm{mL}$ untuk grafin multi-lapisan yang terhasil (Xu et al. 2013). Teknik pengelupasan yang berdasarkan polimer adalah sangat sesuai untuk dijual sebagai bahan pengantara sebelum ia disiapkan sebagai satu produk di kilang pembekal seterusnya.

Dalam pada itu, walaupun teknik pengelupasan cecair sudah pun dikomersialkan oleh Angstron Materials dan Thomas Swan, pengetahuan asas untuk protokol umum amat berbeza antara satu penyelidik dengan penyelidik yang lain (Ren \& Cheng 2014). Sebagai contoh, masa sonikasi semasa pengelupasan yang dilaporkan di dalam kertas penyelidikan mempunyai julat yang besar iaitu antara 30 min dan 1000 jam (Ciesielski \& Samorì 2014). Kualiti, kestabilan dan hasil pengeluaran grafit nanoplat yang terhasil juga tidak lengkap sebab ramai penyelidik cuma menggunakan mikroskopi elektron transmisi untuk menunjukkan kewujudan lapisan grafin tanpa maklumat kuantitatif yang lain. Satu lagi kelemahan teknik pengelupasan cecair ialah grafit nanoplat yang terhasil mempunyai saiz lateral yang kurang daripada 1 $\mu \mathrm{m}$ disebabkan oleh langkah penapisan dan retakan satahdalam semasa pengelupasan (Bonaccorso et al. 2012). Saiz ini menjadikannya kurang sesuai sebagai agen penguat dalam pembuatan komposit.

\section{INTERKALASI-PENGELUPASAN}

Walaupun teknik interkalasi-pengelupasan dikelaskan sebagai satu teknik yang unik dan berbeza, teknik ini mempunyai banyak persamaan dengan teknik yang lain kerana hampir semua teknik menggunakan molekul seperti $\mathrm{CO}_{2}$ dan garam bisulfat atau litium untuk meresapi dan 
melonggarkan grafit sebagai langkah pertama, sebelum langkah pengelupasan yang melibatkan satu sumber tenaga seperti haba, boleh berlaku (Edwards \& Coleman 2013; Parviz et al. 2016). Daripada segi definisi, teknik interkalasi-pengelupasan tidak mengoksidakan grafit dengan asid atau agen pengoksidaan yang lain dalam langkah pertamanya tetapi sesetengah syarikat penghasil grafin masih menggunakan agen pengoksida sebagai agen interkalasi untuk meningkatkan hasil dan produktiviti mereka.

Teknik interkalasi yang dipelopori oleh XG Sciences menggunakan gelombang mikro atau radio berfrekuensi $2.45 \mathrm{GHz}$, sebagai sumber tenaga untuk mengelupaskan grafit menjadi grafit nanoplat selepas grafit tersebut dironggakan oleh asid sulfurik $\left(\mathrm{H}_{2} \mathrm{SO}_{4}\right)$ atau campuran $\mathrm{H}_{2} \mathrm{SO}_{4}$ dengan asid fosforik $\left(\mathrm{HPO}_{3}\right.$ ) (Drzal et al. 2006). Teknik gelombang mikro atau radio frekuensi ini boleh menghasilkan grafit nanoplat yang berkeluasan 50-100 $\mathrm{m}^{2} / \mathrm{g}$ dengan nisbah aspeknya dalam lingkungan 100 sehingga 10,000 (Drzal et al. 2006).

Teknik interkalasi juga dikaji oleh Wright State University bersama Nanotek Instruments Inc. yang menggunakan gas seperti helium dan nitrogen untuk mengelupaskan grafit dalam atmosfera yang bertekanan tinggi (Jang et al. 2006). Hasilnya ialah grafit nanoplat yang terdiri daripada 20 lapisan (Jang et al. 2006). Teknik ini juga boleh digabungkan dengan teknik pembuatan komposit selepas grafit nanoplat ini dikumpul pada akhir proses tersebut (Jang et al. 2006).

Syarikat yang menggunakan teknologi interkalasipengelupasan ialah XG Sciences dari Amerika Syarikat manakala syarikat China yang terlibat ialah Ningbo Morsh dan Deyang Carbonene Tech (Ren \& Cheng 2014). Walaupun teknik ini biasanya menghasilkan grafit nanoplat yang agak tebal tetapi sesetengah pengeluar seperti Deyang Carbonene berjaya menghasilkan grafin multi-lapisan yang kurang daripada 10 lapisan grafin dengan konduktiviti elektriknya setinggi $1000 \mathrm{Scm}^{-1}$ dan hasil pengeluaran pula melebihi 90 \% bt. (Ren \& Cheng 2014).

\section{PENGOKSIDAAN-PENGELUPASAN-PENURUNAN}

Teknik penghasilan GO atau rGO ini juga mempunyai sejarah yang panjang dan ia sudah pun dikomersialkan oleh syarikat China seperti Sixth Element Materials, Tianjin Plannano Technology dan syarikat Amerika Syarikat seperti Vorbeck Materials (Ren \& Cheng 2014). Secara amnya, langkah pengoksidaan ini biasanya dilakukan dengan kaedah yang dipelopori oleh Brodie (1860), Hummers Jr. dan Offeman (1958) serta Staudenmaier (1898) atau pun teknik yang dimodifikasikan daripada kaedah ini (Norhakim et al. 2014). Kaedah Hummers menggunakan kalium permaganat $\left(\mathrm{KMnO}_{4}\right)$ dan asid sulfurik $\left(\mathrm{H}_{2} \mathrm{SO}_{4}\right)$ manakala kaedah Brodie dan kaedah Staudenmaier menggunakan kalium klorat $\left(\mathrm{KClO}_{3}\right)$ dan asid nitrik $\left(\mathrm{HNO}_{3}\right)$ untuk mengoksidakan grafit kepada grafit oksida. Kumpulan oksida dalam grafit oksida akan meregangkan ikatan yang akhirnya terpisah untuk menjadi grafin oksida (GO) semasa pengelupasan. Asid lain yang digunakan dalam langkah pengoksidaan termasuk asid perklorik, asid hipoklorous, asid asetik, asid oksalik, asid klorosulfonik dan asid nitrous (Liu et al. 2007). Asid ini juga dibantu oleh agen pengoksida yang lain seperti dikromat, hidrogen peroksida dan perklorat manakala pelarutnya ialah aseton, metanol dan benzena. Campuran grafit dengan pelarut-asid ini dieram di dalam kebuk yang dipanaskan sehingga suhunya mencapai setinggi $90^{\circ} \mathrm{C}$ selama 10 jam (Liu et al. 2007).

Dalam pada itu, penyelidik dari Chonam National University menggunakan campuran hidrogen peroksida dan ammonia peroksi disulfat dalam langkah pengoksidaan sebelum radiasi gelombang mikro dan sonikasi digunakan untuk mengelupas grafit oksida (Oh et al. 2010). Para penyelidik dari Dow Global pula menggunakan grafit nitronium daripada tindak balas antara grafit dengan $\mathrm{H}_{2} \mathrm{SO}_{4}$ dan asid nitrik $\left(\mathrm{HNO}_{3}\right.$ ) yang cair (Leugers et al. 2007). Grafit nitronium ini dirawat dengan natrium klorat $\left(\mathrm{NaClO}_{3}\right)$ sebelum dipanaskan ke suhu setinggi $1500^{\circ} \mathrm{C}$ untuk menurukan GO kepada rGO (Leugers et al. 2007). Vorbeck Materials pula meningkatkan suhu pengelupasan dari $300^{\circ} \mathrm{C}$ ke $2000^{\circ} \mathrm{C}$ untuk menghasilkan GO yang mempunyai keluasan spesifik $2600 \mathrm{~m}^{2} / \mathrm{g}$ berbanding dengan $300 \mathrm{~m}^{2} / \mathrm{g}$ sebelum pengelupasan (Prud'Homme et al. 2005). Keluasan teori spesifik untuk grafin lapisan ialah $2630 \mathrm{~m}^{2} / \mathrm{g}$ (Zhu et al. 2010).

Walaupun pengoksidaan grafit memudahkan langkah pengelupasan, pengoksidaan berlebihan boleh menyebabkan kerosakan struktur dan pengurangan konduktiviti elektrik kepada GO. Tambahan pula, langkah penurunan untuk GO juga kurang berkesan untuk GO yang terlekat kepada substrat. Oleh sebab itu, para penyelidik dari Universiti California Los Angeles menggunakan hidrazina kontang (98\%) untuk menurunkan grafit oksida kepada lapisan $\mathrm{GO}$ di atas wafer $\mathrm{Si} / \mathrm{SiO}_{2}$ (Tung et al. 2009; Yang et al. 2008). Grafit oksida bergabung dengan hidrazina kontang untuk membentuk hidrazinum grafin (HG) melalui pembentukan ion-berlawanan. Larutan HG menurun kepada grafin multi-lapisan di atas substrat apabila ia dipanaskan ke suhu serendah $150^{\circ} \mathrm{C}$ (Tung et al. 2009). Selain langkah-langkah yang dibentangkan di sini, para pembaca yang berminat juga boleh merujuk kepada kertas kajian ini yang dikhaskan untuk langkah penurunan GO kepada rGO (Pei \& Cheng 2012).

Sehubungan itu, GO dan rGO adalah stabil dalam air atau pelarut akues sebab kumpulan oksida seperti karboksil, epoksi dan hidroksil yang tersebar di atas permukaannya memberi sifat hidrofilik kepadanya untuk berinteraksi dengan polimer di sekelilingnya. Sifat inilah yang menjadikannya sesuai digunakan sebagai agen penguat di dalam komposit berbanding dengan lapisan grafin yang bebas daripada sebarang pengoksidaan. Di sini, harus diingatkan bahawa GO dan rGO cuma sesuai untuk digunakan di dalam polimer hidrofilik seperti asid akrilik dan kurang sesuai untuk polimer hidrofobik seperti polistirena dan polipropilena. Kestabilan rGO dan GO di dalam pelarut-pelarut akues atau organik mempunyai 
hubung-kait dengan kekutuban pelarut, ketegangan permukaan serta parameter kelarutan Hansen dana Hildebrand (Konios et al. 2014). Secara amnya, pelarut yang sesuai untuk menyerak dan menstabilkan grafin mempunyai kekutuban pelarut yang ketara, ketegangan permukaan dan parameter kelarutan Hildebrand yang hampir sama dengan rGO dan GO (Konios et al. 2014).

Selain daripada sifat kimia permukaan ini, rGO adalah lebih berkesan daripada CNT sama ada SWCNT atau MWCNT sebagai serat penguat di dalam komposit kerana permukaan spesifiknya yang luas (Rafiee et al. 2009). Dalam kajian tersebut, epoksi yang diperkukuhkan oleh rGO meningkatkan modulus elastiknya sebanyak $31 \%$ berbanding dengan peningkatan sebanyak $3 \%$ untuk komposit yang diperkuatkan oleh SWCNT (Rafiee et al. 2009). Daripada segi kekuatan muktamad, MWCNT cuma memperkuatkan komposit tersebut sebanyak $14 \%$ berbanding dengan rGO yang meningkatkan kekuatan muktamadnya sebanyak $40 \%$ daripada kekuatan asal epoksi tersebut (Rafiee et al. 2009).

\section{JENIS, NEGARA PENGELUAR DAN KELUARAN GRAFIT SEDUNIA}

Oleh kerana grafit merupakan bahan mentah dalam penghasilan grafin, bahagian ini membincangkan jenis grafit yang berada di pasaran sedunia dan negara pengeluarnya. Walaupun grafit boleh dihasilkan daripada petroleum kok terkalsin atau arang batu pic, kualiti grafit sintetik ini adalah sangat rendah, mahal (hampir 10× lebih mahal daripada grafit semula jadi) dan tidak sesuai untuk penghasilan grafin (Graphite 2016). Jadual 3 menunjukkan tiga jenis grafit yang dilombong dan dijual di pasaran sedunia iaitu grafit amorfus, grafit serpihan dan grafit urat/ longgokan (NouveauMonde 2016). Grafit amorfus adalah berkualiti rendah dengan peratusan karbonnya dalam lingkungan $70-80 \%$ dan ia biasanya digunakan di kilang refraktori dan keluli (Graphite 2016). Sembilan puluh peratus daripada keluaran grafit amorfus dunia berasal dari China. Rajah 6 pula menunjukkan China merupakan pengeluar grafit terbesar di dunia untuk jumlah keseluruhan grafit, diikuti oleh India dan Brazil (NouveauMonde 2016).

Grafit serpihan adalah lebih berkualiti daripada grafit amorfus. Grafit serpihan sesuai untuk digunakan dalam bateri litium ion dan teknnologi hijau yang lain. Kandungan karbon dalam grafit serpihan adalah di antara $85 \%$ dan 98\% (Graphite 2016). Grafit inilah yang paling banyak digunakan sebagai bahan mentah untuk grafin. Walaupun harga grafit serpihan boleh mencapai empat kali ganda lebih tinggi daripada harga grafit amorfus, harga grafit masih rendah berbanding dengan harga grafin. Harga grafit ialah AS\$1-2/kg manakala harga grafit nanoplat ialah AS\$40-1200/kg dan grafin multi-lapisan pula berharga AS\$60-100/cm² (Corporation 2016, Products 2016, Sciences 2016).

Kebanyakan grafit urat berasal dari Sri Lanka dan ia biasanya digunakan sebagai refraktori yang berkualiti tinggi disebabkan oleh kandungan karbonnya yang tinggi iaitu dalam lingkungan 90-99\% karbon (Graphite 2016). Rajah 7 pula menunjukkan kegunaan utama grafit sebagai refraktori dan bateri terutama dalam bateri litium ion (NouveauMonde 2016). Kegunaan grafit dalam penghasilan grafin masih kecil berbanding dengan keluaran grafit sedunia yang dijangka dalam lingkungan 1.1 juta tan setahun (NouveauMonde 2016). Kegunaan untuk penghasilan grafin bersama dengan pembuatan bateri dijangka bertambah penting pada masa akan datang kerana nilai tambahnya yang tinggi dan pertumbuhan pesat dalam bidang bateri kereta elektrik.

\section{SAIZ PASARAN GRAFIn DAN KAJIAN KES TENTANG PENGELUPASAN GRAFIT}

\section{SAIZ PASARAN GRAFIN}

Mengikut anggaran IDTechEx, saiz pasaran grafin sebagai bahan mentah dijangka meningkat ke AS\$220 juta menjelang tahun 2026 (Ghaffarzadeh 2016) manakala Lux meramal saiz pasaran ini adalah sebesar AS\$349

JADUAL 3. Keluaran grafit sedunia berdasarkan jenis atau sifat fizikal

\begin{tabular}{ccc}
\hline No & Jenis grafit & Keluaran sedunia (\%) \\
\hline 1 & Amorfus & $55 \%$ \\
2 & Serpihan & $45 \%$ \\
3 & Urat/longgokan & $<1 \%$ \\
\hline
\end{tabular}

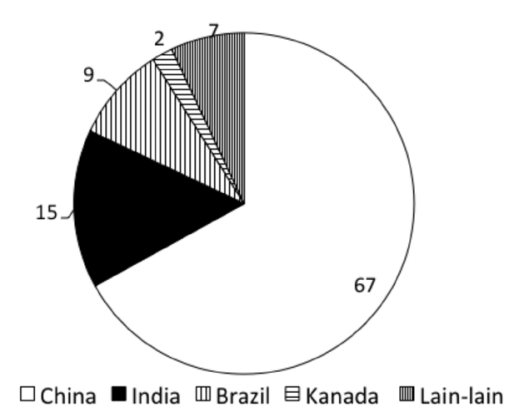

RAJAH 6. Peratusan keluaran grafit sedunia berdasarkan negara pengeluar

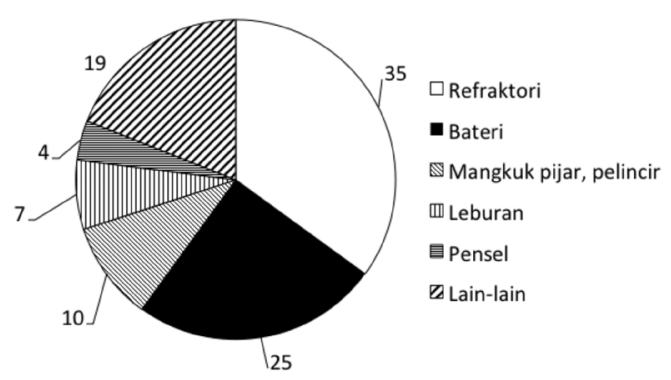

RAJAH 7. Peratusan kegunaan grafit sedunia berdasarkan aplikasi 
juta untuk keseluruhan teknologi grafin menjelang tahun 2025 (Peplow 2015). Nilai pasaran grafin anggaran IDTechEx cuma melibatkan harga mentah grafin dan bukan nilai-tambah yang lain. Saiz pasaran untuk produk yang berteraskan grafin cuma bernilai AS\$12 juta pada tahun 2013 (Zurutuza \& Marinelli 2014). Perbezaan saiz pasaran antara tahun 2013 dengan tahun 2025 atau 2026 memberikan satu peluang besar untuk mengeksploitasi bidang ini.

Kami meramalkan nilai tambah dan saiz pasaran untuk produk berteraskan grafin akan meningkat berlipat-ganda kerana peratusan berat yang digunakan dalam produk tersebut adalah sangat kecil. Ini jelas ditunjukkan dalam Jadual 4 untuk peratusan kegunaan grafin dalam empat aplikasi utama. Jumlah jualan grafin (dalam berat) dijangka mencapai 3800 tan metrik pada tahun 2026 (Ghaffarzadeh 2016). Potensi pasaran ini boleh mencecah 890-1100 ribu tan metrik jika empat aplikasi utama berhijrah ke teknologi grafin berdasarkan keluaran pada tahun 2013 (Jadual 4) (Arvidsson et al. 2013). Ramalan ini adalah agak agresif kerana bukan semua aplikasi akan berhijrah ke teknologi grafin tanpa menimbangkan kelebihan kos atau prestasi.

Dalam pada itu, keluaran grafin berdasarkan permintaan semasa cuma dijangka mencecah 120 tan metrik setahun untuk tahun 2015 dan 1200 tan metrik menjelang tahun 2019 (Zurutuza \& Marinelli 2014). Berdasarkan Rajah 8 (2015), kapasiti keluaran grafin sedunia ialah 909 metrik tan (Peplow 2015). Perbezaan antara permintaan dan kapasiti pengeluaran pada tahun 2015 menunjukkan lebihan bekalan grafin di pasaran semasa berbanding dengan permintaan. Perbezaan ini akan menurunkan harga grafin nanoplat ataupun grafin multi-lapisan supaya lebih berdayasaing dengan teknologi semasa. Seterusnya, penurunan harga grafin dijangka menarik lebih ramai pengguna untuk mencuba teknologi ini kerana potensi pasarannya adalah sangat besar seperti ditunjukkan dalam Jadual 4.

Dalam pada itu, peratusan jualan grafit nanoplat dijangka meningkat dari $75 \%$ (pada tahun 2013) ke $90 \%$ daripada jumlah jualan grafin sedunia pada tahun 2026, berbanding dengan grafin lapisan (Ghaffarzadeh 2016). Pasaran grafit nanoplat ini juga meliputi GO dan rGO. Seperti yang dibincangkan sebelum ini, grafit nanoplat merupakan bahan mentah reaktif yang utama untuk teknologi komposit dan simpanan tenaga. Kegunaan utama untuk grafin ini juga disahkan oleh pembekal grafin di Amerika Syarikat (Segal 2009).

\section{KAJIAN KES: PENGELUPASAN GRAFIT}

Berikut ialah satu kajian kemudah-capaian yang berdasarkan teknologi pengelupasan grafit yang digunakan oleh Aztrong Taiwan (Huang 2016). Teknologi pengelupasan grafit ini mampu untuk mengeluarkan $140 \mathrm{~kg}$ grafin nanoplat setiap hari jika satu sistem ini dijalankan oleh satu syif pekerja. Jika dua syif pekerja menjalankan sistem tersebut, $280 \mathrm{~kg}$ mampu dikeluarkan setiap hari. Jumlah keluaran tahunan untuk sistem ini dijangka mencapai 100 tan metrik jika sistem ini berjalan secara dua syif pekerja setiap hari.

Berdasarkan struktur kos yang diberi oleh Aztrong, kami melakukan satu analisis sensitiviti seperti yang ditunjukkan dalam Jadual 5. Secara amnya, teknologi ini

JADUAL 4. Jangkaan keluaran grafin sedunia berdasarkan keluaran tahunan polistyrena, epoksi, fiber kaca dan getah yang dapat memanfaatkan teknologi grafin (Arvidsson et al. 2013)

\begin{tabular}{lccc}
\hline Bahan & $\begin{array}{c}\text { Keluaran tahunan } \\
\left(10^{6} \text { ton metrik }\right)\end{array}$ & $\begin{array}{c}\text { Kandungan grafin diramalkan } \\
(\% \text { jisim })\end{array}$ & $\begin{array}{c}\text { Jangkaan keluaran grafin } \\
\left(10^{3} \text { tan metrik }\right)\end{array}$ \\
\hline Polistirena & 15 & $0.1-1$ & $15-150$ \\
Epoksi & 1.7 & 0.1 & 1.7 \\
Fiber kaca & 3.8 & $1-3$ & $38-114$ \\
Getah & 21 & 4 & 840 \\
Jumlah & - & & $890-1100$ \\
\hline
\end{tabular}

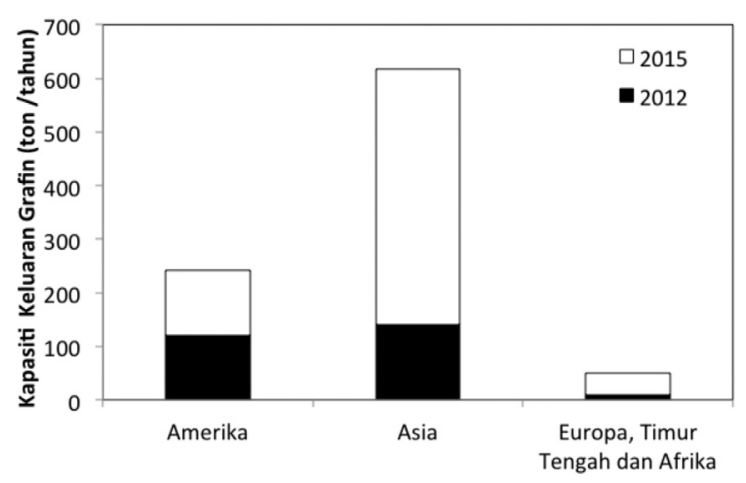

RAJAH 8. Kapasiti keluaran grafin (dan grafit nanoplat) sedunia untuk tahun 2012 dan 2015 (Peplow 2015) 
mampu membawa pulangan lumayan melebihi 50\% jika harga jualan untuk grafin mencapai AS\$100/kg. Pulangan ini masih belum mengambil kira faktor lain seperti bayaran cukai dan faedah, analisis skala dan risiko operasi yang tidak dapat ditentukan dalam kiraan ini (Parviz et al. 2016). Jika harga grafin turun kepada AS $\$ 40 / \mathrm{kg}$, peratusan pulangan akan susut kepada $22 \%$ dan ia akan mendatangkan kerugian $-0.5 \%$ jika harga grafin turun kepada AS $\$ 20 / \mathrm{kg}$. Harga grafin sudah pun turun kepada AS $\$ 40 / \mathrm{kg}$ bagi sesetengah gred di pasaran (Sciences 2016). Dalam senario terakhir (AS\$20/ $\mathrm{kg}$ ), kos pembangunan sistem grafin ini harus diturunkan atau kos operasi hendaklah dikurangkan daripada $40 \%$ kepada peratusan yang lebih berpatutan untuk menjamin pemulangan modal dalam perlaburan ini.

\section{CABARAN TEKNOLOGI GRAFIN DAN KESIMPULAN}

Selain masalah susutan harga grafin mentah, teknologi penghasilan grafin terutamanya teknik pengelupasan perlu mempertimbangkan soalan-soalan berikut semasa membangunkan satu sistem penghasilan grafin:

Bagaimana menghasilkan jenis grafin yang berkualiti dengan konsisten dan dalam kapasiti yang mencukupi untuk aplikasinya? Bagaimana mengurai dan mengukur grafin supaya kualitinya boleh dijamin semasa simpanan dan jualan? Bagaimana menyimpan dan mengangkut grafin dengan selamat tanpa memudaratkan kesihatan para pekerja? dan Bagaimana melipat-gandakan nilai produk pengguna dengan kegunaan grafin?

Sesetengah soalan ini sudah pun dijawab pada permulaan kertas ini. Kualiti grafin yang terhasil bergantung kepada proses yang dipilih dalam Rajah 4 dan Jadual 2. Pada masa ini, kualiti grafin biasanya disemak dengan spektroskopi Raman dan perbandingan antara pembekal utama menunjukkan perbezaan kualiti yang ketara antara pembekal yang disenaraikan di dalam Jadual 6 (Amir 2017). Spektra Raman mempunyai tiga puncak yang penting iaitu jalur-G $\left(1580 \mathrm{~cm}^{-1}\right)$, jalur-D $\left(1350 \mathrm{~cm}^{-1}\right)$ dan jalur-2D (2680-2690 $\left.\mathrm{cm}^{-1}\right)$. Secara amnya, nisbah $\mathrm{I}_{\mathrm{D}} / \mathrm{I}_{\mathrm{G}}$ yang meningkat merujuk kepada kecacatan dan kumpulan berfungsi yang bertambah dalam grafin sehingga ketumpatan kecacatan yang tinggi membentuk struktur amorfus untuk menurunkan nisbah $\mathrm{I}_{\mathrm{D}} / \mathrm{I}_{\mathrm{G}}$, manakala nisbah $\mathrm{I}_{2 \mathrm{D}} / \mathrm{I}_{\mathrm{G}}$ bersama dengan lokasi dan bentuk $2 \mathrm{D}$, merujuk kepada bilangan lapisan grafin (Childres et al. 2013).

JADUAL 5. Kos am teknologi penghasilan grafin atau grafit nanoplat berdasarkan teknologi pengelupasan

\begin{tabular}{|c|c|c|c|c|}
\hline \multirow[t]{2}{*}{ No } & \multirow{2}{*}{$\begin{array}{l}\text { Struktur K } \\
\text { kos }\end{array}$} & \multicolumn{3}{|c|}{ Harga (\$AS juta) } \\
\hline & & AS $\$ 100 / \mathrm{kg}$ & AS $\$ 40 / \mathrm{kg}$ & AS $\$ 20 / \mathrm{kg}$ \\
\hline 1 & Kos mendirikan satu sistem penghasilan grafin & $\$ 8$ & $\$ 8$ & $\$ 8$ \\
\hline 2 & Jualan tahunan grafin untuk 100 tan metrik & 10 & 4 & 2 \\
\hline 3 & $\begin{array}{l}\text { Perbelanjaan operasi (overhed) berdasarkan } 40 \% \\
\text { daripada nilai } 100 \text { tan metrik grafin) }\end{array}$ & 4 & 1.6 & 0.8 \\
\hline 4 & Susut nilai tahunan untuk 5 tahun & 1.6 & 1.6 & 1.6 \\
\hline 5 & $\begin{array}{l}\text { Potensi keuntungan tahunan (selepas susut nilai } \\
\text { untuk } 5 \text { tahun) }\end{array}$ & 4.4 & 1.8 & -0.4 \\
\hline 6 & Peratus pulangan (\% daripada perlaburan permulaan) & $55 \%$ & $22 \%$ & $-0.5 \%$ \\
\hline
\end{tabular}

$40 \%$ merupakan peratusan yang biasa digunakan untuk operasi penghasilan grafin

JADUAL 6. Spektra Raman $\left(\mathrm{I}_{\mathrm{D}} / \mathrm{I}_{\mathrm{G}}\right)$ dan $\left(\mathrm{I}_{2 \mathrm{D}} / \mathrm{I}_{\mathrm{G}}\right)$ dan kandungan $\mathrm{C}$ at\% untuk grafin dan grafit nanoplat yang dihasilkan oleh pembekal komersial menggunakan teknologi berlainan (Amir 2017)

\begin{tabular}{|c|c|c|c|c|c|}
\hline Pembekal & Teknologi & Produk & $\mathrm{I}_{\mathrm{D}} / \mathrm{I}_{\mathrm{G}}$ & $\mathrm{I}_{2 \mathrm{D}} / \mathrm{I}_{\mathrm{G}}$ & Karbon $(\mathrm{C}$ at $\%)$ \\
\hline \multirow{2}{*}{$\begin{array}{l}\text { Angstron } \\
\text { Materials }\end{array}$} & \multirow{2}{*}{$\begin{array}{c}\text { Pengelupasan } \\
\text { cecair }\end{array}$} & N006-P & 0.4 & 2.8 & $\geq 95 \%$ \\
\hline & & N008-100-P-10 & $0.15-0.2$ & $0.33-0.48$ & $\geq 96 \%$ \\
\hline \multirow{3}{*}{$\begin{array}{l}\text { Thomas } \\
\text { Swan }\end{array}$} & \multirow{3}{*}{$\begin{array}{c}\text { Pengelupasan } \\
\text { cecair }\end{array}$} & Grafin pelbagai-lapisan & 0.28 & 0.42 & Tiada \\
\hline & & Grafin & $0.1-0.2$ & 0.04 & Tiada \\
\hline & & multilapisan & $0.07-0.1$ & 0.04 & Tiada \\
\hline \multirow{3}{*}{$\begin{array}{l}\mathrm{XG} \\
\text { Science }\end{array}$} & \multirow{3}{*}{$\begin{array}{c}\text { Interkalasi- } \\
\text { pengelupasan }\end{array}$} & xGNP- & 0.15 & 1.59 & $>99.5 \%$ \\
\hline & & M-grade 5 & 0.262 & 0.3 & $>99.5 \%$ \\
\hline & & Panjang lateral: $20 \mu \mathrm{m}$ & 0.24 & 0.3 & $95.5 \%$ \\
\hline $\begin{array}{l}\text { Deyang } \\
\text { Carbonene }\end{array}$ & $\begin{array}{c}\text { Interkalasi- } \\
\text { pengelupasan }\end{array}$ & Panjang lateral: 1 - $5 \mu \mathrm{m}$ & $0.095-0.138$ & 0.38 & tiada \\
\hline
\end{tabular}


Spektroskopi fotoelektron X-ray (XPS) pula digunakan untuk mendapatkan peratusan oksigen untuk membezakan grafin tulen daripada GO dan rGO. Sebagai contoh, rGO yang diturunkan dengan hidrogen pada suhu $450^{\circ} \mathrm{C}$ mempunyai nisbah karbon/oksigen (C/O) sebanyak 15:1 (Wu et al. 2009) manakala grafit asli mempunyai $\mathrm{C} / \mathrm{O}$ sebanyak 256:1 dan GO mempunyai nisbah C/O antara 2:1 dan 3:1 (Gao et al. 2009; Jeong et al. 2008; Szabó et al. 2006).

Selain spektra Raman dan XPS, spektroskopi penyerapan optikal (OAS) juga digunakan secara meluas untuk menganalisis kepekatan grafin atau GO atau rGO yang dijual dalam bentuk cecair dengan unit $\mathrm{gL}^{-1}$. Sifat fizikal dan dimensi juga biasa dimasukkan ke dalam lembaran teknikal data untuk setiap stok grafit nanoplat atau grafin yang dihasilkan. Rajah 9 menunjukkan saiz lateral dan ketebalan grafin yang dihasilkan oleh syarikat komersial. Berdasarkan ketebalan teori sebanyak $0.34 \mathrm{~nm}$ untuk grafin mono-lapisan, hampir semua pembekal grafin di pasaran umum menjual grafin multi-lapisan (melebihi 10 lapisan) walaupun pasaran grafit nanoplatlah yang dijangka menguasai $90 \%$ daripada pasaran grafin sedunia menjelang tahun 2026.

Dalam pada itu, satu inisiatif yang meliputi semua pemegang taruh dalam industri grafin perlu diadakan untuk menyeragamkan penamaan dan kualiti grafin dengan sistem metrologi, kod-kod atau piawaian yang sesuai untuk menangani cabaran pengkomersialan. Sebagai contoh, Pertubuhan Piawaian Antarabangsa (ISO) dan Suruhanjaya Elektrokimia Antarabangsa sudah pun mempelopori kerja penyeragaman daripada sudut metrologi untuk grafin (Pollard 2016). Sistem metrologi adalah penting kerana banyak pihak mempunyai tafsiran yang berbeza untuk definisi grafin dan penamaannya. Kesatuan Antarabangsa
Kimia Tulen dan Gunaan (IUPAC) mendefinisikan lapisan grafin sebagai satu lapisan karbon atom yang berbentuk heksagon yang diikat oleh $\mathrm{sp}_{2}$, sementara tafsiran yang digunakan oleh para penyelidik meliputi beberapa lapisan atom-atom karbon yang berikat $\mathrm{sp}_{2}$. Daripada segi komersial, syarikat pembekal grafin seperti XG Sciences mengeluarkan grafit nanoplat yang mempunyai 16 lapisan karbon manakala syarikat seperti Angstron pula mengeluarkan grafin yang bercirikan mono-lapisan dan grafit nanoplat yang mempunyai 30 lapisan karbon (Segal 2009). Usaha penyeragaman ini sudah pun dimulakan oleh penyelidik akademik dan pembaca yang berminat boleh merujuk kepada kertas ini untuk mendapatkan definisi yang berkaitan (Bianco et al. 2013).

Selain daripada ciri fizikal, ciri penyebaran dan kestabilan grafit nanoplat (i.e. keupayaan zeta) atau GO semasa penyimpanan dan pengedaran juga harus dianalisis dan difahami. Grafit nanoplat biasanya disimpan dan dijual dalam pelarut organik atau akeus atau dalam matrik polimer sebelum grafit nanoplat tersebut diproses menjadi produk akhir di tempat lain. Sesetengah syarikat terpaksa mengeringkan pelarut ini sebelum menggunakan grafit nanoplat ini dalam proses dalaman mereka. Penyimpanan grafit nanoplat, grafin multi-lapisan atau rGO dalam serbuk atau pepejal adalah tidak praktik kerana ketumpatannya yang rendah dan sifat piroforiknya yang mudah terbakar apabila terdedah kepada atmosfera udara. Selain itu, grafit nanoplat merupakan satu nano-bahan yang mungkin memudaratkan kesihatan pekerja yang terdedah kepadanya disebabkan oleh saiznya yang menjangkaui dimensi nano dan ketoksikannya juga bergantung kepada cara sintesisnya. Pada masa ini, kajian ini masih tidak lengkap tetapi setiap nano-bahan yang digunakan di Eropah adalah

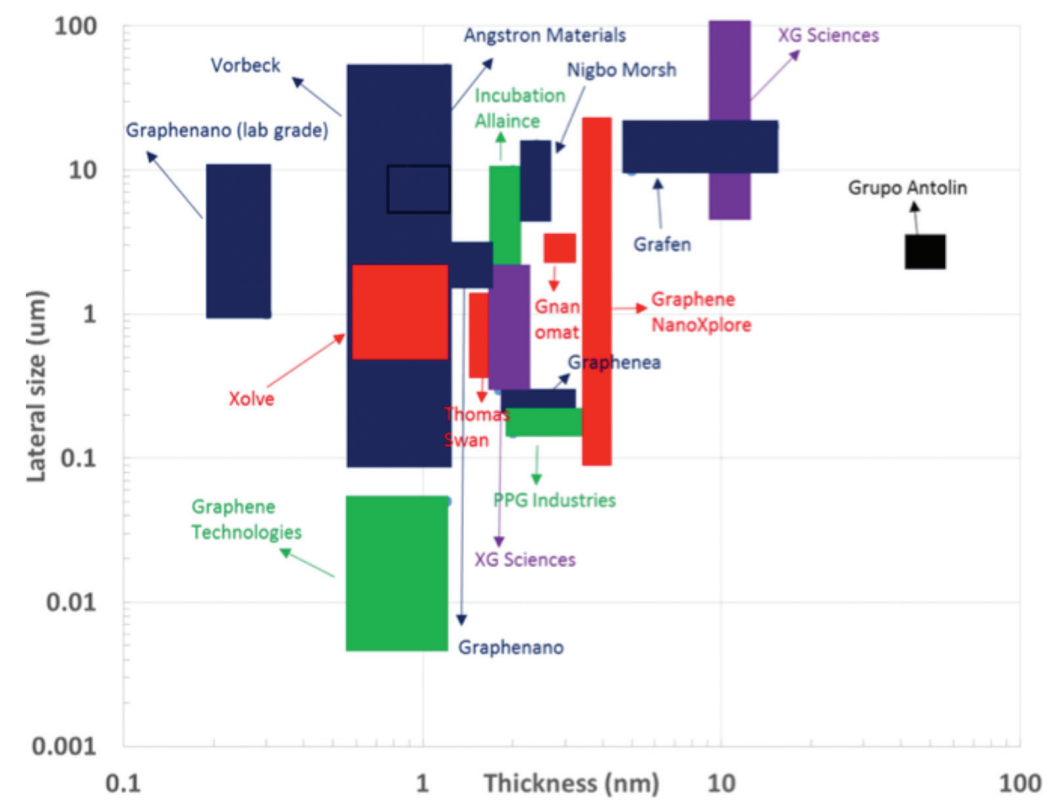

RAJAH 9. Saiz lateral dan ketebalan grafin dan grafit nanoplat yang dijual oleh syarikat komersial (Ghaffarzadeh 2016) 


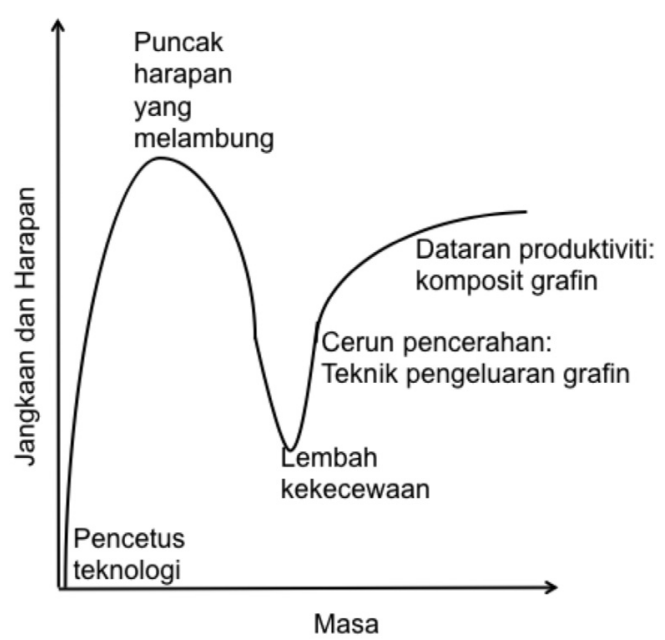

RAJAH 10. Kitar gemburan Gartner yang menunjukkan lima fasa utama untuk teknologi grafin

dikawal dan dipantau di bawah peraturan REACH jika jumlah keluarannya melebihi satu tan metrik setiap tahun (EU 2016).

Daripada segi produktiviti, peratusan berat (\% bt.) biasa digunakan dalam kalangan pengeluar dan ia didefinisikan sebagai nisbah antara berat grafit yang sudah diserak atau dikupas dengan berat asal grafit. Peratusan berat ini tidak memberi gambaran sebenar tentang penghasilan grafit nanoplat dan grafin multi-lapisan. Oleh sebab itu, pencirian lain perlu dilakukan untuk memberi sifat kuantitatif and kualitatif grafin tersebut. Maka, helaian teknikal data syarikat-syarikat pengeluar harus diteliti dan diserasikan dengan proses dalaman di kilang pengguna.

Selain itu, inisiatif penyeragaman ini juga boleh mendefinisikan bahan pengantara yang dapat memanfaatkan sifat grafin dalam produk tersebut. Misalnya, grafit nanoplat boleh dijual dalam bentuk komposit grafin atau 'masterbatch' atau 'resin polimer' untuk diintegrasikan dalam produk akhir seperti cat, salutan, pelincir atau struktur mekanik di peringkat penghasilan seterusnya. Cara ini dapat meningkatkan lagi penggunaan grafin dalam kalangan industri kerana barang-barang pengantara tidak termasuk dalam klasifikasi nano-bahan dan seterusnya mengurangkan kos pematuhan undang-undang dan keselamatan setempat. Pembaca yang berminat boleh merujuk kepada kertas ini yang ditujukan untuk pembuatan komposit yang berteraskan grafin, GO ataupun rGO (Du \& Cheng 2012).

Kesimpulannya, teknologi grafin mula mendapat perhatian ramai sejak anugerah Nobel pada tahun 2010 walaupun aktiviti paten bermula lebih awal dari tarikh tersebut. Setiap teknologi bahan seperti Kevlar dan polietilena akan mengambil masa selama 20 tahun untuk dikomersialkan secara meluas (Zurutuza \& Marinelli 2014). Jika jangka masa 20 tahun diambil sebagai kayu pengukur, pengkomersialan teknologi grafin sudah pun melebihi jangkaan ramai pemegang taruh.
Bagi sesetengah pihak, grafin mungkin menghampiri lembah kekecewaan dalam kitar gemburan Gartner kerana grafin bukanlah penyelamat atau jawapan kepada segala aplikasi yang memerlukan konduktiviti haba atau elektrik yang tinggi. Dalam pada itu, grafin mungkin menuju ke cerun pencerahan daripada segi teknik pengeluaran kerana teknologinya yang sudah seperti dibincang dalam kertas ini. Daripada segi aplikasi komposit grafin, produk seperti raket tenis (Head 2016) dan bateri (Vorbeck Materials 2016) sudah pun boleh dibeli di pasaran. Pemasaran grafin untuk aplikasi raket dan bateri mungkin boleh dikatakan berada di fasa 'dataran produktiviti' dalam kitar gemburan Gartner. Industri grafin harus belajar daripada kesilapan pengkomersialan teknologi karbon nanotiub pelbagai dinding (MWCNT) oleh Bayer Materials Science (BMS) yang menutup kilangnya yang mempunyai kapasiti pengeluaran sebesar 260 tan metrik pada tahun 2013 (PlasticToday 2016). Kesilapan BMS adalah terlalu menumpukan perhatian kepada pembinaan kapasiti pengeluaran MWCNT tanpa menyedari bidang aplikasi sesuai untuk teknologi MWCNT yang tidak mempunyai banyak pertindihan dengan produk teras syarikat BMS. Oleh itu, pertumbuhan industri grafin akan bertambah pesat jika bidang aplikasi grafin dapat dikenal pasti dari awal sejajar dengan jenis, kualiti dan pernambahan kapasiti pengeluaran grafin tersebut.

\section{PENGHARGAAN}

Kami merakamkan setinggi-tinggi penghargaan dan sokongan kewangan daripada Kementerian Pendidikan Tinggi Malaysia untuk Dana LRGS/2015/UKM-UKM/ NANOMITE/04/01 dan Universiti Kebangsaan Malaysia untuk Dana Impak Perdana DIP-2015-008. Kami juga ingin merakamkan penghargaan kepada Amir Mohd yang menyediakan Jadual 6 dalam kertas ini.

\section{RUJUKAN}

Advanced Graphene Products - General Presentation Advanced Graphene Products. ubahan terakhir Nov 30, 2016. https:// advancedgrapheneproducts.com/download-en/.

Amir, Mohd. 2017. Development of graphene-enabled NEMS devices. Master's Thesis, Universiti Kebangsaan Malaysia (tidak diterbitkan).

Arvidsson, R., Molander, S. \& Sandén, B.A. 2013. Review of potential environmental and health risks of the nanomaterial graphene. Human and Ecological Risk Assessment: An International Journal 19(4): 873-887.

Bayer Materials Science exits carbon nanotube business, Plastics Today, ubahan terakhir 10 Dis $2016 \mathrm{https}: / / w w w . p l a s t i c s t o d a y$. com/content/bayer-materialscience-exits-carbon-nanotubebusiness/97630387718802

Bianco, A., Cheng, H.M., Enoki, T., Gogotsi, Y., Hurt, R.H., Koratkar, N., Kyotani, T., Monthioux, M., Park, C.R. \& Tascon, J.M. 2013. All in the graphene family-a recommended nomenclature for two-dimensional carbon materials. Carbon 65: 1-6.

Bonaccorso, F., Lombardo, A., Hasan, T., Sun, Z., Colombo, L. $\&$ Ferrari,A.C. 2012. Production and processing of graphene and $2 \mathrm{~d}$ crystals. Materials Today 15(12): 564-589. 
Bourlinos, A.B., Georgakilas, V., Zboril, R., Steriotis, T.A. \& Stubos, A.K. 2009. Liquid-phase exfoliation of graphite towards solubilized graphenes. Small 5(16): 1841-1845.

Brodie, B. 1860. Sur le poids atomique du graphite. Annales de Chimie et de Physique 59(466): e472.

Chia, J.S.Y., Tan, M.T.T., Khiew, P.S., Chin, J.K. \& Siong, C.W. 2016. A facile one-step green synthesis of graphene by mild solvent exfoliation. Science of Advanced Materials 8(6): 1177-1186.

Chia, J.S.Y., Tan, M.T.T., Khiew, P.S., Chin, J.K., Lee, H., Bien, D.C.S. \& Siong, C.W. 2014. A novel one step synthesis of graphene via sonochemical-assisted solvent exfoliation approach for electrochemical sensing application. Chemical Engineering Journal 249: 270-278.

Childres, I., Jauregui, L.A., Park, W., Caoa, H. \& Chena, Y.P. 2013. Raman spectroscopy of graphene and related materials. New Developments in Photon and Materials Research.pp. 403-418.

Choi, W., Lahiri, I., Seelaboyina, R. \& Kang, Y.S. 2010. Synthesis of graphene and its applications: A review. Critical Reviews in Solid State and Materials Sciences 35(1): 52-71.

Ciesielski, A. \& Samorì, P. 2014. Graphene via sonication assisted liquid-phase exfoliation. Chemical Society Reviews 43(1): 381-398.

Coleman, J. \& Paton, K. 2013. A scalable process for producing exfoliated defect-free non-oxidised 2-dimensional materials in large quantities. US20160009561A1. Difailkan pada Mac 14, 2013 dan diluluskan/dikeluarkan pada Jan 14, 2016.

Drzal, L., Fukushima, H., Rook, B. \& Rich, M. 2006. Method of creating ultra-fine particles of materials using a high-pressure mill. US20060241237.

Du, J. \& Cheng, H.M. 2012. The fabrication, properties, and uses of graphene/polymer composites. Macromolecular Chemistry and Physics 213(10-11): 1060-1077.

Edwards, R.S. \& Coleman, K.S. 2013. Graphene synthesis: Relationship to applications. Nanoscale 5(1): 38-51.

Gao, W.,Alemany,L.B.,Ci,L.\& Ajayan, P.M. 2009. New insights into the structure and reduction of graphite oxide. Nature Chemistry 1(5): 403-408.

Geng, J., Kong, B.S., Yang, S.B. \& Jung, H-T. 2010. Preparation of graphene relying on porphyrin exfoliation of graphite. Chemical Communications 46(28): 5091-5093.

Ghaffarzadeh, K. 2016. Graphene, 2D materials and carbon nanotubes: Markets, technologies and opportunities 20162026. IDTechEx. http://www.idtechex.com/research/ reports/graphene-2d-materials-and-carbon-nanotubesmarkets-technologies-and-opportunities-2016-2026-000465. asp?viewopt $=$ desc.

Graphene: Quest for the Killer App. Nerac. ubahan terakhir Dis 13, 2016. http://www.nerac.com/graphene-quest-killer-app/.

Graphite 101. 2016. Focus Graphite. http://www.focusgraphite. com/technology/.

GrapheneXT tennis racquet. Head. ubahan terakhir Dis 2, 2016. http://www.head.com/en/sports/tennis/technology/graphene$\mathrm{xt} /$

Hasegawa, S. and Kamiya, N.: Graphene powder, apparatus for producing graphene powder, method for producing graphene powder, and product using graphene powder. US20160280551A1. difail Dis 17, 2013 dan diluluskan/ dikeluarkan Sept 29, 2016.

Hernandez, Y., Nicolosi, V., Lotya, M., Blighe, F.M., Sun, Z., De, S., McGovern, I.T., Holland, B., Byrne, M., Gun'ko, Y.K., Boland, J.J., Niraj, P., Duesberg, G., Krishnamurthy, S., Goodhue, R., Hutchison, J., Scardaci, V., Ferrari, A.C. \&
Coleman, J.N. 2008. High-yield production of graphene by liquid-phase exfoliation of graphite. Nature Nanotechnology 3(9): 563-568.

Huang, K.T. 2016. Graphene Commercialization: Challenges and Opportunities. Graphene Malaysia 2016. Kuala Lumpur: Nano Malaysia \& Phantoms Foundations 1.

Hummers Jr., W.S. \& Offeman, R.E. 1958. Preparation of graphitic oxide. Journal of the American Chemical Society 80(6): 1339.

Jang, B., Zhamu, A. \& Guo, J. 2006. Mass production of nanoscaled platelets and products. US7785492B1.

Janowska, I., Begin, D., Chizari, K., Ersen, O., Bernhardt, P., Romero, T., Ledoux, M. \& Pham-huu, C. 2009. Preparation of graphene by mechanically thinning graphite materials. US9309122B2.

Jeong, H-K., Lee, Y.P., Lahaye, R.J., Park, M-H., An, K.H., Kim, I.J., Yang, C-W., Park, C.Y., Ruoff, R.S. \& Lee, Y.H. 2008. Evidence of graphitic $\mathrm{AB}$ stacking order of graphite oxides. Journal American Chemical Society 130(4): 1362-1366.

Konios, D., Stylianakis, M.M., Stratakis, E. \& Kymakis, E. 2014. Dispersion behaviour of graphene oxide and reduced graphene oxide. Journal Colloid Interface Science 430: 108-112.

León, V., Quintana, M., Herrero, M.A., Fierro, J.L., de la Hoz, A., Prato, M. \& Vazquez, E. 2011. Few-layer graphenes from ballmilling of graphite with melamine. Chemical Communications 47(39): 10936-10938.

Leugers, M., Nickless, B., Paquette, M., Cieslinski, R. \& Shu, T. 2007. Highly efficient process for manufacture of exfoliated graphene. US8246856B2.

Lin, T., Tang, Y., Wang, Y., Bi, H., Liu, Z., Huang, F., Xie, X. \& Jiang, M. 2013. Scotch-tape-like exfoliation of graphite assisted with elemental sulfur and graphene-sulfur composites for high-performance lithium-sulfur batteries. Energy \& Environmental Science 6(4): 1283-1290.

Liu, L., Xiong, Z., Hu, D., Wu, G. \& Chen, P. 2013. Production of high quality single-or few-layered graphene by solid exfoliation of graphite in the presence of ammonia borane. Chemical Communications 49(72): 7890-7892.

Liu, Z., Zhou, X., Qin, Z. \& Tang, C. 2007. Method for preparing graphene. US9162894B2.

Lotya, M., Hernandez, Y., King, P.J., Smith, R.J., Nicolosi, V., Karlsson, L.S., Blighe, F.M., De, S., Wang, Z. \& McGovern, I. 2009. Liquid phase production of graphene by exfoliation of graphite in surfactant/water solutions. Journal of the American Chemical Society 131(10): 3611-3620.

Matawinie graphite project: high purity flake graphite deposit in North America Nouveau Monde. ubahan terakhir Dis 10, 2016. http://nouveaumonde.ca/wp-content/uploads/2016-0914-Nouveau-Monde-Corporate-Presentation.pdf.

Mazurkiewicz, M. \& Conrad, B. 1999. Method of creating ultra-fine particles of materials using a high-pressure mill. US6824086B 1 .

Multi-walled carbon nanotube (773840) Sigma-Aldrich. ubahan terakhir Dis 7 2016. http://www.sigmaaldrich.com/catalog/ product/aldrich/773840?lang=en\&region=MY.

Norhakim, N., Ahmad, S.H., Chia, C.H. \& Huang, N.M. 2014. Mechanical and thermal properties of graphene oxide filled epoxy nanocomposites. Sains Malaysiana 43(4): 603-609.

Novoselov, K.S.,Fal'Ko, V.I., Colombo, L., Gellert, P.R., Schwab, M.G. \& Kim, K. 2012. A roadmap for graphene. Nature 490(7419): 192-200.

Novoselov, K., Geim, A., Morozov, S., Jiang, D., Zhang, Y., Dubonos, S., Grigorieva, I. \& Firsov, A. 2004. Electric field effect in atomically thin carbon films. Science 306(5696): 666-669. 
Nuvoli, D., Valentini, L., Alzari, V., Scognamillo, S., Bon, S.B., Piccinini, M., Illescas, J. \& Mariani, A. 2011. High concentration few-layer graphene sheets obtained by liquid phase exfoliation of graphite in ionic liquid. Journal of Materials Chemistry 21(10): 3428-3431.

O’Neill, A., Khan, U., Nirmalraj, P.N., Boland, J. \& Coleman, J.N. 2011. Graphene dispersion and exfoliation in low boiling point solvents. Journal of Physical Chemistry C 115(13): 5422-5428.

Oh, I.K., Sridhar, V. \& Jeon, J. 2010. Method for the fabricating graphene nanosheets, and graphene nanosheets fabricated using the method WO2011083896.

Overview of XG Sciences and Our Materials, XG Sciences, ubahan terakhir Nov 29, 2016. http://xgsciences.com/products/ graphene-nanoplatelets/.

Parviz, D., Irin, F., Shah, S.A., Das, S., Sweeney, C.B. \& Green, M.J.2016. Challenges in liquid-phase exfoliation, processing, and assembly of pristine graphene. Advanced Materials 28(40): 8796-8818

Parviz, D., Das, S., Ahmed, H.T., Irin, F., Bhattacharia, S. \& Green, M.J. 2012. Dispersions of non-covalently functionalized graphene with minimal stabilizer. ACS Nano 6(10): 8857-8867.

Patents owned by GPC. Graphene Platform Corporation, ubahan terakhir Nov 30, 2016. http://grapheneplatform.com/ technology/architecture/.

Paton, K.R., Varrla, E., Backes, C., Smith, R.J., Khan, U., O’Neill, A., Boland, C., Lotya, M., Istrate, O.M., King, P., Higgins, T., Barwich, S., May, P., Puczkarski, P., Ahmed, I., Moebius, M., Pettersson, H., Long, E., Coelho, J., O'Brien, S.E., McGuire, E.K., Sanchez, B.M., Duesberg, G.S., McEvoy, N.,Pennycook, T.J., Downing, C., Crossley, A., Nicolosi, V. \& Coleman, J.N. 2014. Scalable production of large quantities of defect-free few-layer graphene by shear exfoliation in liquids. Nature Materials 13(6): 624-630.

Pei, S. \& Cheng, H.M. 2012. The reduction of graphene oxide. Carbon 50(9): 3210-3228

Peplow, M. 2015. Graphene booms in factories but lacks a killer app. http://www.nature.com/news/graphene-booms-infactories-but-lacks-a-killer-app-1.17771.

Pollard, A.J. 2016. Metrology for graphene and 2D materials. Measurement Science and Technology 27(9): 092001.

Pop, E., Mann, D., Wang, Q., Goodson, K. \& Dai,H. 2006. Thermal conductance of an individual single-wall carbon nanotube above room temperature. Nano Letters 6(1): 96-100.

Prud'Homme, R., Aksay, I., Adamson, D. \& Abdala, A. 2005. Thermally exfoliated graphite oxide. US7658901B2.

Qian, W., Hao, R., Hou, Y., Tian, Y., Shen, C., Gao, H. \& Liang, X. 2009. Solvothermal-assisted exfoliation process to produce graphene with high yield and high quality. Nano Research 2(9): 706-712.

Rafiee, M.A., Rafiee, J., Wang, Z., Song, H., Yu, Z-Z. \& Koratkar, N. 2009. Enhanced mechanical properties of nanocomposites at low graphene content. ACS Nano 3(12): 3884-3890.

Regulation (EC) No. 1907/2006 - REACH. 2006. European Agency Safety at Work. https://osha.europa.eu/en/legislation/directives/ regulation-ec-no-1907-2006-of-the-european-parliament-andof-the-council.

Ren, W. \& Cheng, H.M. 2014. The global growth of graphene. Nature Nanotechnology 9(10): 726-730.

Schlierf, A., Yang, H., Gebremedhn, E., Treossi, E., Ortolani, L., Chen, L., Minoia, A., Morandi, V., Samori, P. \& Casiraghi, C. 2013. Nanoscale insight into the exfoliation mechanism of graphene with organic dyes: Effect of charge, dipole and molecular structure. Nanoscale 5(10): 4205-4216.
Segal,M. 2009. Selling graphene by the ton. Nature Nanotechnology 4(10): 612-614.

Spitalsky,Z., Tasis, D., Papagelis, K.\& Galiotis, C. 2010. Carbon nanotube-polymer composites: Chemistry, processing, mechanical and electrical properties. Progress in Polymer Science 35(3): 357-401.

Staudenmaier, L. 1898. Verfahren zur darstellung der graphitsäure. Berichte der Deutschen Chemischen Gesellschaft 31(2): 1481-1487.

Szabó, T., Berkesi, O., Forgó, P., Josepovits, K., Sanakis, Y., Petridis, D. \& Dékány, I. 2006. Evolution of surface functional groups in a series of progressively oxidized graphite oxides. Chemistry of Materials 18(11): 2740-2749.

Thostenson, E.T., Ren, Z. \& Chou, T.W. 2001. Advances in the science and technology of carbon nanotubes and their composites: A review. Composites Science and Technology 61(13): 1899-1912.

Tung, V.C., Allen, M.J., Yang, Y. \& Kaner, R.B. 2009. Highthroughput solution processing of large-scale graphene. Nature Nanotechnology 4(1): 25-29.

UK-IP-Office. 2015. Graphene the worldwide patent landscape in 2015. U. I. I. Team. UK, Intellectual Property Office UK.

Vor-Power $^{\mathrm{TM}}$ Flexible Battery Strap. Vorbeck Materials, ubahan terakhir Dis 2, 2016. http://store.vorbeck.com/collections/ vor-power-flexible-battery-straps/products/vor-power-athena/

Wu,Z-S., Ren, W., Gao, L., Liu, B., Jiang, C. \& Cheng, H-M. 2009 Synthesis of high-quality graphene with a pre-determined number of layers. Carbon 47(2): 493-499.

Xu, L., McGraw, J-W., Gao, F., Grundy, M., Ye, Z., Gu, Z. \& Shepherd, J.L. 2013. Production of high-concentration graphene dispersions in low-boiling-point organic solvents by liquid-phase noncovalent exfoliation of graphite with a hyperbranched polyethylene and formation of graphene/ ethylene copolymer composites. Journal of Physical Chemistry C 117(20): 10730-10742.

Yang, Y., Kaner, R., Tung, C-C. \& Matthew, A. 2008. Highthroughput solution processing of large scale graphene and device applications. US9105403.

Zhou, K.G., Mao, N.N., Wang, H.X., Peng, Y.\& Zhang, H.L. 2011. A mixed-solvent strategy for efficient exfoliation of inorganic graphene analogues. Angewandte Chemie-International Edition 50(46): 10839-10842.

Zhu, Y., Murali, S., Cai, W., Li, X., Suk, J.W., Potts, J.R. \& Ruoff, R.S. 2010. Graphene and graphene oxide: Synthesis, properties, and applications. Advanced Materials 22(35): 3906-3924.

Zurutuza, A. \& Marinelli, C. 2014. Challenges and opportunities in graphene commercialization. Nature Nanotechnology 9(10): 730-734.

Institut Mikro-Juruteraan dan Nanoelektronik

Universiti Kebangsaan Malaysia

43600 UKM Bangi, Selangor Darul Ehsan

Malaysia

*Pengarang untuk surat-menyurat; email:kimsiow@ukm.edu.my

Diserahkan: 21 Disember 2016

Diterima: 25 Januari 2017 